\title{
Between License and Responsibility Reexamining the Role of the Poet in Twenty-First-Century Chinese Society
}

\author{
Heather Inwood
}

While the era of Reform and Opening Up released poets from the ideological restraints of earlier periods to pursue "art for art's sake," the growing gap between the rich and poor and the mass human migrations to crowded urban centers from still-impoverished rural provinces have forced poets to again reflect on the relationship between poetry and society. According to sinologist Heather Inwood, this dichotomy can be traced to the inception of modern Chinese poetry-poets struggled with the simultaneous need to invent new forms of vernacular poetry while placing poetry in the service of the nation and revolutionary politics. If poetry written in the late-1970s through the '90s is known for its cosmopolitan, formally experimental poetics, many poets writing in the new millennium reveal a new leftism that stresses populist, straightforward vernacular poetry that seeks to serve China's working classes, migrant laborers, and the disenfranchised.

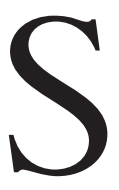

ince the mid-2000s, the Chinese poetry scene has witnessed a proliferation of discourse that focuses on the preferred relationship between poetry and reality. Opinions differ greatly over to what extent poets are bound to use their writing to reflect upon and critique current social realities, and in what ways poetry can best be used to give form to poets' experiences and understanding of contemporary China. In their search for a literary justification for contemporary poetry's continued existence in an indifferent, increasingly consumerist world, many poets and critics have turned to the theme of poetic responsibility. They suggest that the poet's duty to portray the world around themspecifically the Chinese social world-should come before experimentations with aesthetics or technique. A sense of responsibility places the poet firmly within the Chinese intellectual tradition of worrying about the country and the people, and adds sociopolitical purpose to the act of writing poetry. To those who disagree with these views, however, such a reductive way of looking at artistic creation reeks of political correctness and a lack of poetic imagination.

What do such differing opinions mean for the role of the poet in China today, and what are the poetic and moral implications of the various arguments that poets have put forward? By examining more closely several examples of what I term a "post-Internet language of responsibility," it may be easier to understand what is at stake in contested visions of contemporary poethood, and of poetry's place within society and culture at large. Behind the examples of poetic discourse explored in this essay is found, I believe, the continued influence of a dichotomous way of thinking about modern Chinese poetry that can be traced back to the Republican era, which holds that poetry should be either for life or for poetry. Many key polemics that have taken place within the post-2000 Chinese poetry scene can, in some way, be traced back to this dichotomy. Ultimately, the central question remains: Are poets responsible to contemporary Chinese society with a duty to speak as public intellectuals to sociopolitical actualities? Or should poets primarily be concerned with their poetic art, regardless of how in touch their writing might be with the lives of the Chinese masses?

The reemergence of this divide in recent Chinese poetry criticism can be linked to the current situation contemporary poets find themselves in vis-à-vis the economy, society, media, and politics. Connections can also be made between the post-Internet language 
of responsibility and trends observable in other cultural forms, such as documentary cinema and performance art, that highlight the social context of the filmmaker or artist during the creative process, and which give rise to new forms of realism. For many poets, a widely experienced sense of responsibility stems from both a common investment in the scene of contemporary poetry and from a deep-rooted belief in the importance of the poet as a public intellectual who has a duty to Chinese society despite-or perhaps because of-poetry's widely acknowledged marginalization within mainstream culture.

\section{Republican Era Debates}

$\mathrm{T}$ he divide between poetry for poetry's sake (wei shige de shige 为诗歌的诗歌) and poetry for life's sake (wei shenghuo de shige 为生活的诗歌) has assumed multiple forms in the history of modern and contemporary Chinese poetry. Among the earliest instances was a 1920s polemic between proponents of populism (pingmin zhuyi 平民主义), including poets Hu Shi 胡 适 and Yu Pingbo 俞平伯, and writers who believed that New Poetry ( $x$ in shi_新诗) belonged to the noble classes, such as Kang Baiqing 康白情 and Liang Shiqiu 梁实秋. At the heart of this polemic was a fundamental disagreement over the best direction for New Poetry. While $\mathrm{Hu}$ and $\mathrm{Yu}$ advocated the incorporation of colloquialisms and everyday subject matter in New Poetry in order to serve a wider audience, Kang, Liang, and others held that New Poetry's only responsibility was to itself - as Liang put it, "art exists for art, poetry is written for poetry." 1 Although participants in such debates no doubt exaggerated the extent of their poetic divisions in order to stake a position for their respective journals and associations within the literary scene of the time, ${ }^{2}$ aesthetic and ideological divisions between poetry for life's sake and poetry for poetry's sake continued to grow in the first half of the twentieth century. By the mid-1940s they had become fully politicized, and when the People's Republic of China was established in 1949 it was clear that an overarching cultural policy of art for life- or more accurately art for politics- had at least won the short-term battle.

\section{The Live Scene Debate}

B $y$ the turn of the new millennium, modern Chinese poetry had largely freed itself of its earlier political shackles, and what had begun as a limited underground space for avant-garde poetic production in the 1960s and '70s had burgeoned into a flourishing literary field. Internally, however, the poetry scene was just as divided in the year 2000 as it had been during the 1920s. A polemic that erupted in 1999 at the Panfeng Poetry Meeting (Panfeng shihui 盘峰诗会) had brought long-simmering resentments between socalled Popular Standpoint (minjian lichang 民间立场) poets and Intellectual poets (zhishifenzi shiren 知识分 子诗人) into the open. Maghiel van Crevel summarizes the differences between the two sides using two trends he calls the Earthly and the Elevated. "Earthly" alludes to qualities such as quotidian, colloquial, anticultural, realist, ordinary, indigenous, of the body, and popular, while "Elevated" denotes all that is heroic, literary, cultural, utopian, elitist, Westernized, of the mind, and intellectual. ${ }^{3}$ This dichotomous mindset can be observed in most poetry criticism that emerged as the Panfeng Polemic continued to play out on the Internet and in print publications in the first few years of the 2000s.

Among the most outspoken and longstanding proponents of the Popular Standpoint, or Earthly poetics, is Yunnan poet Yu Jian 于坚. In his 1993 essay "What Are Poets For?," Yu described the common predicament of poets living in the late-twentieth-century market economy, whose motivations, intellectual goals, and social relevance were seeming less and less certain. According to Yu, poets in the 1990s were left with just two options: "Either accept responsibility and exist as a poet of the 'live scene.' Or refuse to 'be rejected,' continue to indulge in utopia's pessimistic cynicism, and ... refuse the 'current moment,' the 'live scene' and the 'present at hand' [shoubian 手边]." Yu concluded that the direction contemporary poets would likely take is away from utopian thinking and toward poetic reflections upon their existence. The essay ends as follows: "Great poetry is about revealing, and leading people back to the live scene of their existence. Great, healthy poetry will lead us to escape from the spiritual jail of utopia, and to return, healthily and freely, to humanity's 'live scene,' 'current moment,' and 'present at hand."'4 This was the first time in contemporary poetry discourse that the word “live scene" (xianchang 现场) had been employed to refer to a particular approach to poetry writing. The term is widely used in photography, performance art, theater, and film criticism to describe an emphasis on the here-and-now. Among the scholars who have used the term in English-language scholarship is Zhang Zhen, who asserts the importance of the live scene to Jia Zhangke's 贾樟柯 film making. Zhang defines it as "a particular social and epistemic space in which orality, performativity, and an irreducible specificity 
of personal and social experience are acknowledged, recorded, and given aesthetic expression.. ${ }^{5}$ There are parallels here with Chris Berry's concept of "getting real," which he views as a powerful trend in contemporary Chinese documentary filmmaking, a kind of "on-the-spot realism" whose spontaneity and unscripted qualities contribute to a "new vision of the real." " In any cultural genre, to state that a work of art possesses liveness (xianchangxing 现场性) or a live feeling (xianchanggan 现场感) is to recognize its temporal and spatial ontology, to emphasize its sense of reality, and to grant extra critical weight to the place and moment of production.

Following the rapid growth of the online poetry scene in the early 2000s, the terms "live scene" and "liveness" became increasingly used in poetry criticism. Among frequent users is the poet Yi Sha 伊沙, who employs a newly evolved understanding of the "live scene" as the original locations and times when poetry activity takes place (as in the "live scene of poetry”). Along with Shen Haobo 沈浩波, cofounder of the Lower Body (Xiabanshen 下半身) poetry group, Yi also makes reference to the "bodily live scene" (shenti xianchang 身体现场) in order to link his and the Lower Body group's body-writing (shenti xiezuo 身体 写作) of the early 2000s to the Internet, which many poets view as the most happening space of the avantgarde poetry scene. By the mid-2000s, some poets had begun to complain that the term "live scene" was losing its critical impact, turning into a synonym for the poetry scene rather than the philosophical construct originally employed by Yu Jian. In the postscript to the 2006 edition of the unofficial poetry journal Poem Time (Shige xianchang 诗歌现场), editor Duoyu 朵渔 wrote:

We must have the courage to return. We must have the courage to reveal ourselves. We must have the courage to complete ourselves. Thus we propose: return to the live scene! This live scene is no longer a happy-go-lucky world of vagabonds, and does not simply refer to poetry circles. It is instead the live scene of existence, the live scene of the soul, the live scene of the motherland. We must have courage to face up to life's truths, the courage to speak the truth of the facts, the strength to face the soul. ${ }^{7}$

In the second edition of the journal, Duoyu further questioned the usefulness of the term "live scene," citing poet Kouzhu's 口诸 reminder that the live scene does not directly correspond to the current moment (dangxia 当下), as well as Kouzhu's belief that "good poetry, indeed, permanently maintains some form of liveness."

By 2007, the notion of the live scene had become embroiled in poetry politics, used by various poets to explain their poetic views and critique the writings of others. Baiya 白鸦, for example, suggested that the live scene was being increasingly mistaken for the contemporaneity principle. He expressed disapproval of terms like "bodily live scene" and accused Shen Haobo, Yi Sha, and Yu Jian of having created a "fake live scene discourse." "These accusations were met with rebuttal on the Internet poetry forum Poetry Vagabonds (Shi jianghu 诗江湖), where poets called them a "cruel disavowal of our writing." 10 Others attempted to clarify what was at stake in the debate, making a distinction between a live scene that is "the gathering place of writers and their works," and the "more primitive" live scenes of life itself, which could also be understood as the "internal spiritualization of real life" through poetry. ${ }^{11}$

\section{The Petty Literati Debate}

A nother poetic debate that took place in 2006 A made the language of responsibility even more explicit. This was a discussion around the topic of Petty Literati Poetry that began at the First Lushan New Century Summit of Famous Poets, a large-scale poetry event held in Changsha in June 2006, organized by the poet and architect Tan Kexiu 谭克修. On the second day of the summit Tan gave a speech defending his own poetry against criticism raised during a roundtable discussion the night before that it was insufficiently artistic. He did so by launching an attack on what he termed "petty literati poetry" (xiao wenren shige 小文人诗歌), written by poets who lead a "traditional literati-style life," who are "deaf to all that goes on beyond their windows ... spending every day inside their offices, in front of computers and piles of paper, producing poetry that deals only with the self and which is completely divorced from reality and the masses." As Tan put it,

Petty literati poetry does not focus on questions of reality, but rather on so-called poetic technique, including issues related to linguistic, rhetorical, and stylistic technique. This type of poet and this type of writing has no relevance to the current era. If one were to situate such prattling petty literati poetry within a larger historical perspective it would all be revealed to be ineffectual writing. ${ }^{12}$ 
The topic of Petty Literati Poetry was further expanded upon by poetry critic Li Shaojun 李少君, editor of the literary journal Horizon (Tianya 天涯), who gave a speech espousing New Critical Realist Poetry (xin pipan xianshizhuyi shige 新批判现实主义 诗歌) and critiquing introspective trends in contemporary poetry. After the summit ended, Petty Literati Poetry became a hot topic of debate online as many well-known poets spoke up in both agreement and disagreement with Tan. Typical of essays written in support of Tan Kexiu's poetics was Shen Haobo's "Can Poets Face Up to the Times?" in which he stated, "From the 'Third Generation' to today, we poets ... have not truly, specifically faced up to reality. In fact, this society and this era have already offered up a vast reality, but the majority of poets ignore it." ${ }^{13}$ Poets who took the other side of the argument included Shen's former Lower Body comember Duoyu, who argued that "Poetry is primarily a spiritual endeavor, it is linguistic creation ... it is important that we should not let 'the times' shackle poetry's feet-poetry is not 'one project and one discussion,' it is not the mouthpiece of the times!"14 The discussion was featured in a number of national and regional newspapers, and although it touched upon a broad range of issues related to the writing and criticism of contemporary Chinese poetry, most arguments could be traced back to the age-old poetry for poetry versus poetry for life divide.

\section{Grassroots Poetry}

$\mathrm{T}$ he debate on Petty Literati Poetry overlapped with growing discussion in poetry circles of grassroots poetry (caogen shige 草根诗歌). This term was first clarified by Li Shaojun in his 2003 essay "Searching for the Grassroots Essence of Poetry." In it, Li claimed that advocating grassroots essence was "the key to searching for originality or new areas of growth in contemporary Chinese poetry." Furthermore, whether or not a poem possesses grassroots essence (caogenxing 草根性) depends on whether "you can get from reading it a sense of the poet's background, living conditions, unique personal experiences, and even his or her education and temperament." ${ }^{15} \mathrm{Li}$ contrasted grassroots essence with the conceptuality (guannianxing 观念性) that he detected in many less successful contemporary Chinese poems, then proceeded to put these poetic views into practice while editing the 2006 poetry anthology Twenty-First-Century Poetry Selection: Grassroots Poetry Edition (21 shiji shige jingxuan: caogen shige teji 21世纪诗歌精选: 草根诗歌特辑). Poets he deemed representative of grassroots poetry included Yang Jian 杨键, Lei Pingyang 雷平阳, Huang Canran 黄灿然, Pan Wei 潘维, and Tan Kexiu 谭克修.

That grassroots poetry discourse was able to gain traction in the poetry scene may in part be due to the way it subsumes other threads in contemporary Chinese poetry criticism, including Individual Writing (gerenhua xiezuo 个人化写作), and emphasizes the native experience (bentu jingyan 本土经验) advocated by many Third Generation (di san dai 第三 代) poets. ${ }^{16}$ By 2008, the terms "grassroots essence" and "grassroots writing" were being broadly used to denote any poem that appeared to be rooted in a specifically Chinese, often lower-class, kind of reality. It was also used to describe amateur poets who could be found among the people rather than in poetry anthologies, such as the netizen (wangmin 网民) poets who contributed to the Quake Poetry movement (dizhen shichao 地震诗抄) following the Wenchuan earthquake of May 2008. ${ }^{17}$

Other critical terms that have been used in association with grassroots poetry include "migrantworker poetry" (dagong shige 打工诗歌), "lower-rung writing” (diceng xiezuo 底层写作), “peasant poetry" (nongmin shige 农民诗歌), and “Low Poetry” (di shige 低诗歌) with its associated "School of Rubbish" (laji pai 垃圾派) and "Rubbish Movement" (laji yundong 垃圾运动) poetry groups. ${ }^{18}$ Poetry scholar Wu Sijing 吴思敬 summarizes these writing trends “as facing the lower rungs" (mianxiang diceng 面向底层), calling them "an attention-grabbing direction for poetry in the new century." ${ }^{19}$ The numbers of poets and critics who support the poetry of migrant workers, who espouse a return to grassroots, and who advocate a poetic focus on the lives of China's lower classes suggests, according to $\mathrm{Wu}$, that contemporary poetry has made a 180-degree turn since the 1980s when most avant-garde poets were pursuing aesthetic purity and attempting to distance themselves from reality. The words of Liu Dongwu 柳冬妩, the editor of Spiritual Rebirth from the Countryside to the City: Chinese Migrant Worker Poetry Research (Cong xiangcun dao chengshi de jingshen taiji: Zhongouo dagong shige yanjiu 从乡村到 城市的精神胎记: 中国打工诗歌研究), provide a typical example of lower-rung poetics:

The writings of "migrant-worker poets" have restored the tension between writing and historical context, and restored the direct link between text and personal experience....When [migrant-worker poets] truly use their faith, their souls, and their ability to suffer disgrace to raise the flag of writing, their voices may float 
faintly on the world's wild winds, but to us they are precious.

Liu, like many proponents of lower-rung writing, criticizes contemporary Chinese poetry for putting form before content, claiming that nowadays, "Writing poetry is no longer spiritual creation, it has become technique." 20

\section{Whose "Lower Rungs"?}

$\mathrm{T}$ he three examples of recent contemporary poetry discourse examined here are not identical in their concerns and motivations, and thus it is helpful to clarify some of the differences. First, it is primarily established poets and poetry critics who employ terms like "grassroots poetry," "lower-rung writing," and "migrant poetry" to publicize and support the writing of lesser-known, often socio-economically disadvantaged poets. This is often, but not always, socially engaged poetry that stems from the writers' lived experience. Critics such as Li Shaojun see grassroots writing as a fresh source of originality for contemporary Chinese poetry and an alternative direction to the poetic ideas offered by established or professional (zhuanye 专业) poets, such as those associated with the Popular Standpoint or Intellectual Writing. As a broader category, grassroots poets can include anyone not known as an established poet who might turn to poetry in times of need, such as after the 2008 Sichuan earthquake. Migrant-worker poet Zheng Xiaoqiong 郑小琼 is often used as a poster girl for grassroots and migrant-worker poetry because she first began writing while working in a Dongguan 东莞 factory. She has been awarded the People's Prize for Literature for her prose and become a leading figure among poets born in the 1980s.

Second, criticism of Petty Literati Poetry in connection with a preference for facing the times (miandui shidai 面对时代) or “entering deeply into the contemporary” (shenru dangdai 深入当代), is voiced by established poets who choose to write about current social realities, especially the lives of China's lower socioeconomic groups. These poems are usually not based on lived experience. Yi Sha is among the more prominent practitioners of this, having written a number of poems reflecting the fates of China's most disadvantaged populations, including "China's Lower Classes" (Zhongguo diceng 中国底层), "Suicide Child" (Zisha de xiaohai 自杀的小孩), “Spring Breast Calamity" (Chuntian de rufang jie 春天的乳房劫), and “The Chinese Sense of Reality Comes from a Powerful Actuality You Couldn't
Make Up" (Zhongguo de zhigan laizi xugou buchu de qiangda xianshi 中国的质感来自虚构不出的强大现 实). Given that most poets who write about the hardships of the masses themselves belong to a more affluent intellectual class, this could be viewed as a continuation of China's intellectual tradition of worrying about the country and the people (youguo youmin 忧国忧民), or even the Chinese peasant consciousness (nongmin yishi 农民意识) that became a subject of reevaluation among intellectuals in the 1980s. ${ }^{21}$

The third trend consists of relatively neutral language such as the "live scene" and "liveness," words that imply a focus on contemporary realities but do not require they be limited to certain socio-economic groups. These terms suggest some level of poetic intervention in or critical reflection of contemporary Chinese life by creating a palpable sense of presence and process in the poem itself. There are parallels here with uses of the word "live scene" in other genres of cultural criticism, all of which point to a wresting of the notion of realism from its recent socialist history along the lines of the "on-the-spot realism" or "getting real" described by Chris Berry in his research on contemporary documentary cinema.

Overall, the proliferation of debates and discourse related to poetry's preferred relationship with reality-and contemporary reality in particular-suggest an ongoing renegotiation or reconsideration of the role of the poet in contemporary Chinese society. The examples examined in this article have in common a high level of disagreement over whether poets are responsible for reflecting the times, connecting with the masses, and expressing an awareness of Chinese reality, or whether poets should be given the license to write about whatever they want, in whatever way they want. This disagreement echoes earlier discussion in the Republican era surrounding notions such as popular poetry (pingmin shige 平民诗歌), pure poetry (chunshi 纯诗), and poetry for life or poetry for poetry.

The reemergence now of a language of poetic responsibility could be a result of various factors, many of which can be linked to the growth of the Internet. The latter half of the 2000s in mainland China has witnessed a renewed focus within the mass media on socio-economic inequalities and instances of social injustice. Contemporary poets might be especially inspired by, and may even identify with, the fate of China's more disadvantaged or marginalized populations due to their own marginal status within mainstream culture and society. To some extent this status is desired: maintaining distance from mainstream commercial culture is partly what gives contemporary poets their mystique and enables their identification 
with the avant-garde. A slew of incidents in which contemporary poetry has found itself thrust into the critical glare of the media spotlight has, however, exacerbated feelings of alienation and misunderstanding among those in the poetry scene. The netizen-led spoofing of the female poet Zhao Lihua 赵丽华 in 2007 is one such incident, which resulted in a few of Zhao's shortest and most colloquial poems being ill received by the public as symptomatic of the current state of contemporary Chinese poetry.

Although it highlights the existential challenges faced by China's poets, the growth of the Internet and the ubiquity of computer technologies have provided poets with unprecedented opportunities for poetic interaction, experimentation, group formation, and textual circulation. This means that today's poetry scene is interconnected like never before, with access to seemingly unending volumes of text (poetry) and metatext (criticism, essays, manifestos, forum postings, discussions, and so on). Interconnectedness has also led to a new self-consciousness of the need to participate in poetry discourse and poetic debate in order to be considered an active member of the scene-or the "live scene" - of poetry. The biggest beneficiaries of the new post-Internet order in the poetry scene are possibly poets outside of academia, those living in cities outside of the capital Beijing, and especially those in China's southern provinces-poets who aligned themselves with the "Popular" side of the Panfeng Polemic around the turn of the millennium and whose writings tend toward (according to Maghiel van Crevel) all that is quotidian, colloquial, realist, and ordinary. It is no coincidence that it is poets and critics sympathetic to the Popular Standpoint who have been most active in advocating and practicing a poetic language of responsibility; poets associated with Intellectual Writing have, on the whole, been far quieter on the subject.

\section{Conclusion}

Ome observers of the post-Internet language of $\checkmark$ responsibility examined here have begun to question whether these trends are edging further away from aesthetic criticism and closer to delineating some kind of contemporary poetry ethics (shige lunli 诗歌 伦理) or moral guidelines. Qian Wenliang 钱文亮, for example, has expressed concern that they echo mainstream social discourse a little too closely. Qian suggests that the true responsibility facing poets and critics is not a responsibility toward society demonstrated through writing about society, but rather the "professional ethics" of "maintaining the necessary distance from homogenous fashions in social discourse." 22 Ozaki Humiaki 尾崎文昭 furthers this critique, arguing that migrant-worker literature and lower-rung literature are constituents of new leftist literature (xin zuoyi wenxue 新左派文学), a literary ideology spearheaded since the turn of the millennium by prominent critics including Meng Fanhua 孟繁华, Xie Youshun 谢有顺, and Li Tuo 李驼. ${ }^{23}$ Humiaki sees this trend as having developed gradually since the mid-1990s in response to China's growing social inequalities. Although its frequently critical nature does not necessarily align it with mainstream political interests, because of the thematic similarities between lower-rung literature and Hu Jintao's calls to build a harmonious society (goujian hexie shehui 构建和谐社 会), it has become increasingly difficult to distinguish an independent literary concern for contemporary realities and disadvantaged populations from the Communist Party's need to maintain political stability via putting China's poverty gap and the needs of the masses at the forefront of their ideological agenda.

Given such concerns, what should we make of the emergence and rapid proliferation of a postInternet language of responsibility within mainland China's contemporary poetry scene? Might this sense of responsibility and its accompanying vocabulary of "lower-rung writing," "grassroots essence poetry," "migrant-worker poetry," and so on render contemporary poets' self-identification as avant-garde (xianfeng 先锋) or unofficial (fei guanfang 非官方) somewhat dubitable? I would venture that it would be wrong to accuse contemporary poets of being complicit with state ideology solely on the basis of a poetic concern for social reality. A language of responsibility expressed through poetry is the product of a complex combination of forces and trends of an economic, social, and personal nature, and is tied to contests for discursive power within the poetry scene. There is no doubt that many contemporary poets are genuinely concerned for the hardships faced by less fortunate sections of China's population; that many continue to use poetry as their preferred medium for expressing this concern could be viewed as a reflection of the enduring appeal of this literary genre as a conduit for worrying about the country and the people, as well as evidence that the image of the poet as a public intellectual who speaks on behalf of the masses is still prominent in the minds of many. The proliferation of discourse centered on the divide between social responsibility and poetic license is proof that the role of the poet within contemporary society continues to be the subject of doubt, debate, and renegotiation in China today. 
Notes

1 Liu Jiye 刘继业, Xin shi de dazhonghua he chunshihua 新 诗的大众化和纯诗化 (The Popularization and Pure Poetryification of New Poetry), (Beijing: Peking University Press, 2008), 14.

2 For more on the relationship between different Republican era literary societies see Kirk A. Denton and Michel Hockx (ed.), Literary Societies of Republican China (Lanham, Md.: Lexington Books, 2008).

3 Maghiel van Crevel, Chinese Poetry in Times of Mind, Mayhem, and Money (Leiden: Brill, 2008), 25.

4 Yu Jian 于坚, “Shiren he wei?" 诗人何为 (“What Are Poets For?"), in Yu Jian, Zongpi shouji 棕皮手记 (Notes of the Palm Bark) (Shanghai: Dongfang chuban zhongxin, 1997), 236-238.

5 Zhang Zhen, "Bearing Witness: Chinese Urban Cinema in the Era of 'Transformation,"' in The Urban Generation: Chinese Cinema and Society At the Turn of the Century, ed. Zhang Zhen (Durham: Duke Univ. Press, 2007), 20.

6 Chris Berry, "Getting Real: Chinese Documentary, Chinese Postsocialism," in The Urban Generation: Chinese Cinema and Society At the Turn of the Century, ed. Zhang Zhen (Durham: Duke Univ. Press, 2007), 122.

7 Duoyu 朵渔, “Hui dao xianchang" 回到现场 ("Return to the Live Scene"), in Shige xianchang 1 诗歌现场 1 (Poem Time 1) ed. Duoyu (Tianjin, 2006), 278.

8 Duoyu, “Chuanyue”穿越 (“Traversing”) in Poem Time 2, ed. Duoyu, (Tianjin, 2007), 231.

9 Baiya 白鸦, “Lun Hanyu shige xushu celue de zhuanxing (si): dangxiaxing yuanze: bianqing $\mathrm{Yu}, \mathrm{Yi}$, Shen de wei xianchang shuo" 论汉语诗歌叙述策略的转型（四）: 当下性原则：辨清于、伊、沈的伪现场说 (“On the Changes in Narrative Strategies in Chinese Poetry (Four): Clarifying Yu, Yi, and Shen's Fake Live Scene Discourse"), Bei Dao Poetry Society Blog, accessed November 28, 2010, http://blog.sina.com.cn/s/blog_4be491ff010008e9.html.

${ }^{10}$ Liu Cheng 刘诚, "Wei xianchang shuo wei shenme rang yi xie ren zuo li bu an?" 伪现场说为什么让一些人坐立不 安? ("Why is the Fake Live Scene Discourse Making Some People So Restless?"), Wu Zai's Blog, accessed November 28, 2010, http://blog.sina.com.cn/s/blog_4c2a17d0010094kh. html.

11 Shi Sheng 石生, "Shige de 'xianchang' he 'wei xianchang"' 诗歌的 “现场” 和 “伪现场” (“Poetry's 'Live Scenes' and 'Fake Live Scenes'"'), Poetic Magazine, accessed November 28, 2010, http://www.shigebao.com/html/ articles/12/2302.html.

12 Xiao Wen 小闻, “Xinrui shiren menglie pengji 'xiao wenren shige "' 新锐诗人猛烈抨击 “小文人诗歌'“'Sharp Poets Harshly Criticize 'Petty Literati Poetry'"), Yangcheng Evening News, July 1, 2006, also on Tianya Poetry Forum, accessed November 28, 2010, http://www.tianya.cn/publicforum/ Content/poem/1/100439.shtml.
${ }^{13}$ Shen Haobo 沈浩波, “Shiren neng fou zhimian shidai?" 诗 人能否直面时代? ("Can Poets Face Up to the Times?"), Poemlife, accessed November 28, 2010, http://www. poemlife.com/Wenku/wenku.asp?vNewsld=1557.

${ }^{14}$ Duoyu, "Lun shige zuowei yi zhong ziwo xiuzheng zhi dao, huo: dui changshi de jianshou zongshi hen nan de" 诗歌 作为一种自我修正之道, 或: 对常识的坚守总是很难的 ("On Poetry as a Means of Self-Correction, or: Defending Common Sense Is Always Very Difficult"), Duoyu's blog, accessed November 28, 2010, http://duoyu.blog.hexun. com/4422820_d.html.

${ }^{15}$ Li Shaojun 李少君, “Xunzhao shige de 'caogenxing"' 寻 找诗歌的草根性 ("Searching for the Grassroots Essence of Poetry"), Tianya Poetry Forum, accessed November 28, 2010, http://www.tianya.cn/publicforum/content/ poem/1/11964.shtml.

${ }^{16}$ Qian Wenliang 钱文亮, “Daode guizui yu jieji fuzhou: fansi jinnian lai de shige piping” 道德归罪与阶级符咒 : 反思近年来的诗歌批评 (“Moral Incrimination and Class Charms: Retrospection on Poetry Criticism in Recent Years"),Journal of Jiangnan University 26, no. 6 (2007). Also online, Douban, accessed November 28, 2010, http:// www.douban.com/group/topic/6566827/.

17 For more on Quake Poetry see Heather Inwood, "Multimedia Quake Poetry: Convergence Culture after the Sichuan Earthquake," forthcoming in The China Quarterly.

${ }^{18}$ For more on Low Poetry and the School of Rubbish see Heather Inwood, "Identity Politics in Online Chinese Poetry Groups," Postmodern China (Berliner Chinahefte/ Chinese History and Society), 34 (2008), 77-94.

${ }^{19}$ Wu Sijing 吴思敬, “Mianxiang diceng: shiji chu shige de yi zhong zouxiang" 面向底层 : 世纪初诗歌的一种 走向 (“Facing the Lower Rung: A Poetic Direction in the New Century"), Guangzhou Writers Association Website, accessed November 28, 2010, http://www.gzwhys.com. cn/node_162/node_165/node_343/2006/11/07/1162885 5834141.shtml.

20 Liu Dongwu as cited by Wu Sijing, ibid.

${ }^{21}$ Perry Link, Evening Chats in Beijing: Probing China's Predicament (New York: Newton, 1992), 135.

22 Qian Wenliang, "Moral Incrimination and Class Charms."

${ }^{23}$ Ozaki Humiaki 尾崎文昭, “Diceng xiezuo, dagong shige, xin zuoyi wenxue" 底层写作一一打工诗歌——新左 翼文学 (“Lower-Rung Writing, Migrant Worker Poetry, New Leftist Literature"), China Institute of Strategy and Management, accessed November 28, 2010, http://www. cssm.gov.cn/view.php?id=19927. 